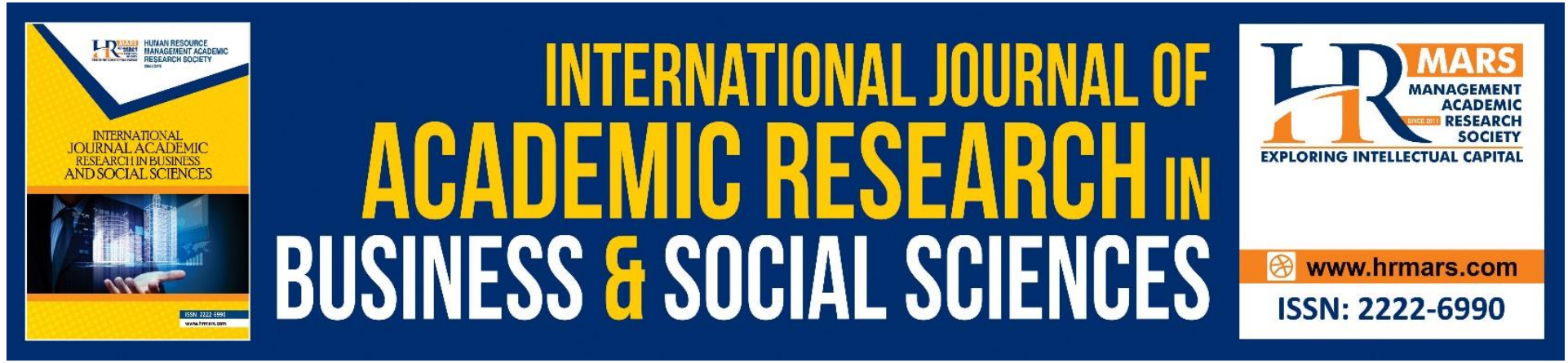

\title{
Economic Literacy and Its Effects on Students' Financial Behavior at Malaysian Public University
}

\section{Sheeril Hing Mei Lyn, Sheerad Sahid}

To Link this Article: http://dx.doi.org/10.6007/IJARBSS/v11-i8/10551

DOI:10.6007/IJARBSS/v11-i8/10551

Received: 07 June 2021, Revised: 12 July 2021, Accepted: 30 July 2021

Published Online: 20 August 2021

In-Text Citation: (Lyn \& Sahid, 2021)

To Cite this Article: Lyn, S. H. M., \& Sahid, S. (2021). Economic Literacy and Its Effects on Students' Financial Behavior at Malaysian Public University. International Journal of Academic Research in Business and Social Sciences, 11(8), 736-750.

Copyright: @ 2021 The Author(s)

Published by Human Resource Management Academic Research Society (www.hrmars.com) This article is published under the Creative Commons Attribution (CC BY 4.0) license. Anyone may reproduce, distribute, translate and create derivative works of this article (for both commercial and non-commercial purposes), subject to full attribution to the original publication and authors. The full terms of this license may be seen at: http://creativecommons.org/licences/by/4.0/legalcode

Vol. 11, No. 8, 2021, Pg. 736 - 750

Full Terms \& Conditions of access and use can be found at http://hrmars.com/index.php/pages/detail/publication-ethics 


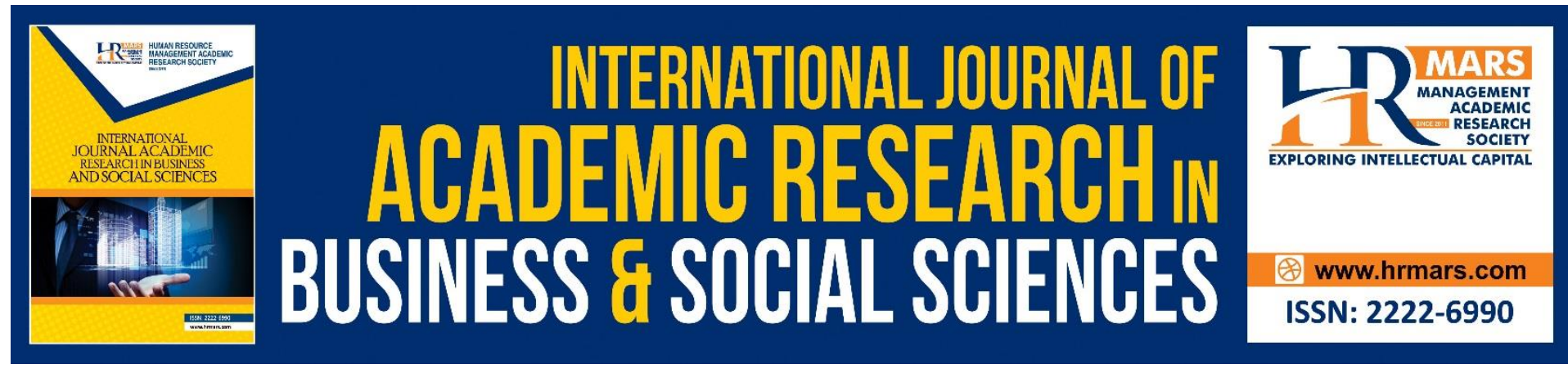

\title{
Economic Literacy and Its Effects on Students' Financial Behavior at Malaysian Public University
}

\author{
Sheeril Hing Mei Lyn, Sheerad Sahid \\ Faculty of Education, Universiti Kebangsaan Malaysia, Bangi, Selangor, Malaysia. \\ Email: sheeril.ukm@gmail.com, sheerad@ukm.edu.my
}

\begin{abstract}
Economic literacy is one of the important life aspects needed by every individual to achieve the increasingly challenging life goals today. All societies, including everyone, are not exempt from their respective responsibilities to know how to manage their finances in order to ensure their future and well-being. This study was conducted to examine the economic literacy of Malaysia Public University (UKM) students and its impact on their financial behavior in terms of spending and saving behavior. This study used a quantitative approach through a survey method by distributing questionnaires to respondents. The sample includes a total of 205 students using a simple random sampling technique. Descriptive and inferential analyses were used to test the hypotheses using Statistical Package for the Social Sciences (SPSS) version 23. The findings of the study indicated that students at the Malaysian public university have a moderate to a high level of economic literacy. Furthermore, economic literacy also has a positive and significant effect on the students' financial behavior. Thus, several suggestions are discussed in this paper to raise awareness about the importance of economic knowledge, especially in terms of financial management among university students.
\end{abstract}

Keywords: Economic Literacy, Financial Behavior, Spending Behavior, Saving, Finances.

\section{Introduction}

First of all, the selection of the research title was made to identify the extent to which the determinants of economic literacy impact financial behavior among UKM students. Additionally, this study also aims to look into the concept of economic literacy, which is related to financial behavior in general. Hence, this study asserts several research problems that cause the issues that occur in this study, such as the financial management of society, especially students and the impact of economic literacy on their financial behavior.

This study outlines three important objectives, which are to examine the level of economic literacy among university students, to identify the university students' financial behavior based on their spending and saving behavior, and to examine the impact of economic literacy on students and their financial behavior. This study also has importance to certain parties including the university, students, and the community. First, future researchers can study this topic in detail to help the university management by forming excellent student personalities in all aspects, especially in terms of their financial management. Next, the importance of this 
study for the students is that the results can help the students address the issue of money scarcity as well as improving their economic literacy by understanding its impact on financial management.

Furthermore, the importance of the study for society is that the results can assist every society member in understanding the importance of economic literacy and the ways of managing finances, especially in this modern era. According to Aisyah and Wajeeha (2016), money is a very important component to fulfill human desires and needs in the rapid economic growth nowadays. Besides, Aisyah and Wajeeha (2016) also stated that the issue of student hunger is due to lack of money, which has become a hot topic on social media. For instance, there was a case where a student from UKM claimed that he had to suffer from hunger and his intestines were consequently affected due to this problem.

\section{Literature Review}

In this era of globalization, economic literacy is a very important component of life, especially considering that life is full of challenges nowadays. This matter needs to be emphasized by society members whereby every individual needs economic literacy to manage their finances and achieve their life goals, regardless of the old or young generation. Thus, each generation has a responsibility to manage finances in order to ensure the future and well-being. According to Yasmin and Anuar (2017), the level of literacy about finances is very important because almost all human life affairs involve finances.

Accordingly, the level of economic literacy and the way of managing finances that are related to decision-making about finances are very important in human life today. Based on a study by Wahid and Zahari (2020), the rising cost of living encourages students to increase their literacy so that they can live a good life. Hence, university students need to improve their economic literacy in order to manage their finances better. Moreover, economic literacy, which is related to financial management, can prevent students from incurring too much debt (Yasmin \& Anuar, 2017).

The concept of economic literacy can be said to interrelate with financial management which, according to Huriyatul and Yogi (2016), is one of the ten intelligences that must be present in each individual. Based on the study by Husniyah and Mohd (2014), financial management or planning starts from the economic field and the financial field. Accordingly, the field of economics and finance has an important relationship with respect to the economic position of an individual in his or her life, such as buying assets, getting married, and so on. Therefore, with the basic knowledge of financial management, individuals who are economics literate will be able to make any decisions easily.

In other words, the higher the level of economic literacy of an individual, the more efficient the individual manages his or her finances. Hence, the individual will know how to manage financial burdens and have strategies to improve financial management continuously. This can be supported by the study by Salbiah et al. (2018), where the way of financial management is interrelated with the knowledge of economics and finance as well as the skills that exist in a person. Furthermore, Wahid and Zahari (2020) also stated that the conflict of financial management among students occurs due to the problem of uncertainty in determining between the needs and wants. 
Such confusion occurs due to the lack of knowledge about financial management among students. In other words, this problem is caused by the students' inability to manage their finances well, along with the emergence of the problem where they cannot distinguish between the aspects of needs and wants. Therefore, a high level of economic literacy in financial management will be able to train each individual, especially students in setting and managing their budget limits. This further indicates that the financial decisions made are very important because financial management without proper decisions will result in over expenditure of the available financial resources.

\section{Underpinning Theories}

The two theories related to this study are the theory of financial behavior and Maslow's Hierarchy of Needs. The theory of financial behavior is basically based on financial theories where a situation related to the financial decisions of an individual reflects the individual's behavior (Khoong, 2015), which involves the elements of risk and return with the element of uncertainty. The theory of financial behavior comprises two types of models, namely the utility expectation model and the prospect model. As for the utility expectation model, utility expectation is more inclined to an individual who makes a rational choice or decision in any circumstances (Khoong, 2017) and this includes four elements.

The first element constitutes the situation where an investor is rational and able to make decisions although in stressful situations. The next element is the situation where an investor does not take more risks for the same return and has a goal to maximize profits. Meanwhile, the prospect model of the financial behaviour theory explains that financial behavior is different among individuals (Khoong, 2015). The profit function is shown in concave form and the loss function is shown in convex form. In this regard, a steeper loss function carries meaning to an individual being more affected by and facing negative emotions when in a losing situation (Khoong, 2017). The next theory is related to the concept of living needs, which is best known as Maslow's theory of needs where society has different needs according to age, gender, and so on.

Every human being needs to have knowledge of the economy in order to realize that financial priorities are what fulfills the needs of his or her life. According to Salbiah et al. (2018), financial literacy is a set of skills and levels of knowledge that enable an individual to make effective decisions related to available financial resources. Furthermore, the actions of an individual's financial management also depend on pre-determined financial goals in order to continue with today's life that is full of challenges. Besides, Sabri and Alavi (2019) explained that the financial planning of each individual is different according to the individual's level of economic literacy in making any decisions related to finances in their life such as savings or spending.

\section{Economic Literacy}

Economic literacy can be divided into three interrelated dimensions, namely the levels of knowledge, behavior, and experience about finances. If an individual has a high level of economic literacy, the higher the individual's finance experience and, in turn, the individual shows a positive attitude towards finance. Thus, we can see that most of the younger generations, especially university students, are more likely to have more unnecessary debt (Rubayah et al., 2015) because, according to Rubayah et al. (2015), these young people are 
more inclined towards their desires, which shows that they only want to fulfill a materialistic lifestyle and have a wasteful attitude.

Furthermore, some young people are stuck in debt due to the high cost of living, which shows their irresponsible attitude towards themselves. In consequence, they are likewise concerned about the current economy and financial management, especially in relation to savings for old age, insurance, investment, and so on. This is because youths are most likely still not ready to be independent and manage their finances (Rubayah et al., 2015). Hence, we can conclude that young people, especially students, are not adequately exposed to skills and knowledge in related fields such as economics to manage their finances effectively in view of the challenges of life today and the high cost of living.

\section{Financial Behavior}

Financial behavior includes several skills including financial management, budget planning and control, as well as savings (Talib et al., 2017). According to Talib et al. (2017), most entrepreneurs do not adopt these three components and this causes the high failure rate of entrepreneurs. This proves that a good level of economic literacy will have a positive effect on the ability to generate financial resources and ensure business progress. If a society has a high level of knowledge about the economy, then they will be able to learn about proper financial planning; however, this insufficiency has been one of the causes for youth failure to manage finances well (Aisyah \& Wajeeha, 2016).

Based on a previous study by Bhushan and Medury (2014), there is a positive relationship between the level of knowledge and financial behavior. In addition, Talib et al. (2017) also indicated that a business that is successfully managed by entrepreneurs by understanding financial aspects including risk management, interest rates and financial markets is more likely to have a high level of financial literacy in economics. Moreover, financial literacy in the economy is also linked to better life plans for retirement and savings. Other than that, financial literacy is an important determinant for a plan to be implemented because it gives a great influence on one's planning, especially an entrepreneur who makes plans for his or her business (Talib et al., 2017).

Having a high level of financial literacy also encourages a person to be more inclined to practice financial savings, which is used as a preparation to face retirement in the future. According to Hussin and Rosli (2019), if parents have good financial management, then their children will emulate this practice. This is supported by Mitchell et al (2009) whereby young people of families with better backgrounds are more likely to have higher levels of economic literacy with financial management. Hence, good financial management is necessary as a strategy, particularly the planning framework to use existing financial resources to achieve life goals in a long-term period.

Based on the study by Rubayah et al (2015), awareness of finance-related knowledge needs to be inculcated and enhanced among students. This is supported by Sabri and Alavi (2019), who stated that the exposure of education regarding economics and finance should be applied at an early stage due to the relatively materialistic lifestyle of youths nowadays. Yet, without an adequate level of economic literacy, an individual may not be able to carry out and manage his or her financial planning properly. Thus, with good financial management, 
each individual can identify his or her current and future financial positions as well as be sensitive to the steps to achieve their life goals.

\section{Conceptual Framework of The Study}

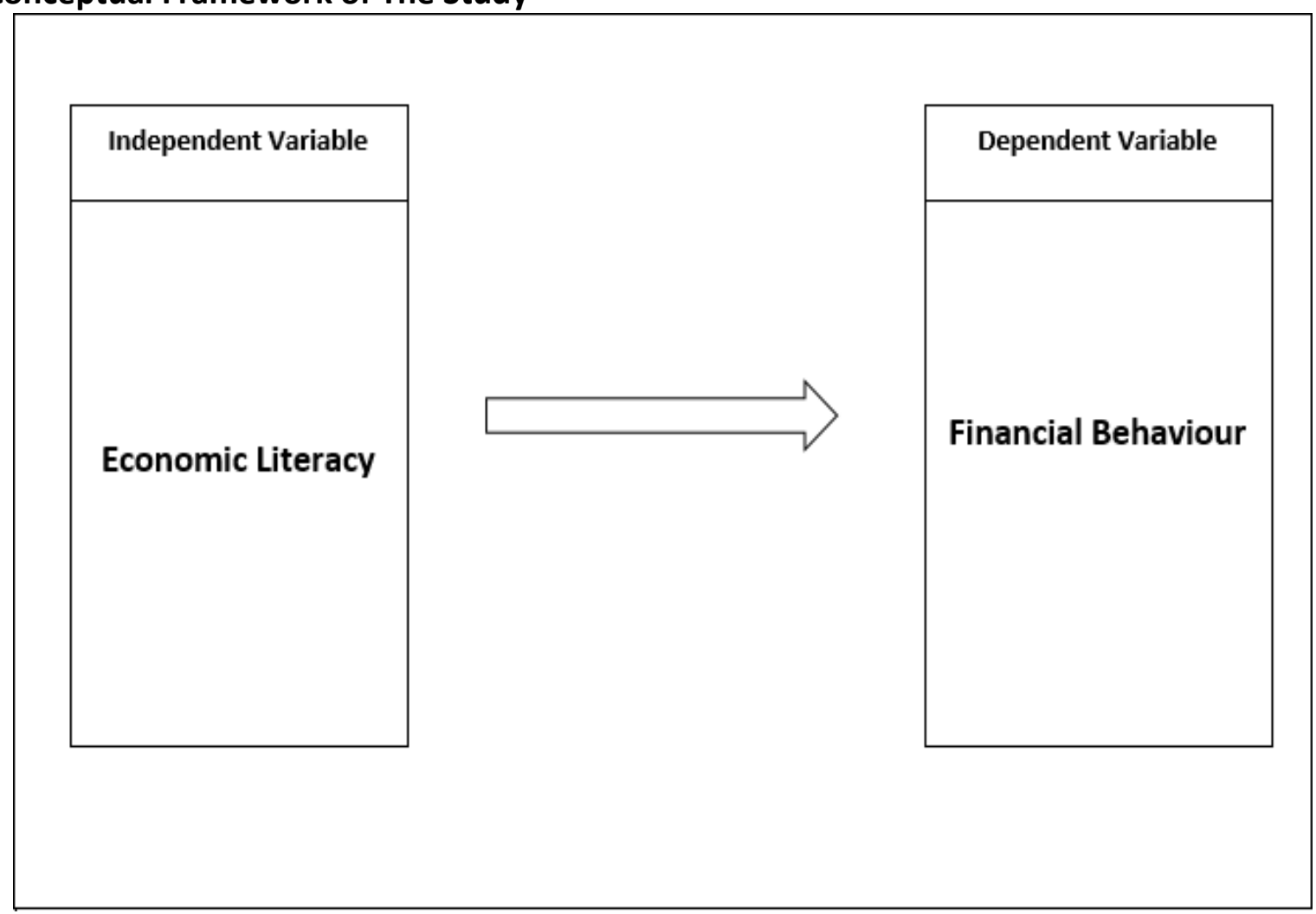

Figure 1: Conceptual Framework

Figure 1 shows the conceptual framework that describes the demographic factors related to the level of economic literacy among university students and the effect of economic literacy on financial management among university students. This framework includes several demographic factors of the students such as gender, field of study, race, family income category, level of education, and year of study as well as the sources of educational sponsorship. The economic literacy level serves as the independent variable in this study, whereas its effect on students' financial behavior serves as a dependent variable.

\section{Research Methodology}

This study was conducted to examine the economic literacy of university students and its impact on their financial behavior in terms of spending and saving behavior. The study was conducted at a public university in Selangor, Malaysia, and the study used a quantitative approach by analyzing primary data collected from the survey questionnaire. A total of 205 sets of questionnaires were distributed to the students including undergraduate and postgraduate students. The questionnaire for this study consists of five sections: Part A entails the demographic data of the respondents, while Part B measures the level of economic literacy among students and Part $C$ measures their financial behavior in terms of spending and saving behavior. Next, Part $D$ examines the effect of economic literacy on students' financial behavior and, finally, Part E requires the respondents to provide their opinions and suggestions regarding the management of economic literacy. 
In this study, each answer from Part B until Part D are designed using a Likert scale that categorizes scores according to the level of financial literacy measurement scores based on Rubayah et al.'s (2015) study. The score value is divided into three levels in which a score greater than zero or less than or equal to 2.99 indicates a poor level of literacy, while the second (medium) level outlines a score value between 3 and 3.99, and the third (high) level outlines a score value between 4 and 5 . In this study, descriptive analysis was conducted to identify the demographic data of the respondents using the frequency and percentage distribution values.

Based on Table 2, reliability tests were performed on the questions outlined in the questionnaire. According to Hasan et al (2017), the reliability index in the test is most satisfactory if the value is 0.60 ; hence, the test results can be identified based on Cronbach's Alpha values exceeding 0.60. Accordingly, a Cronbach's Alpha value above 0.60 indicates that the reliability value is acceptable and at a good level. Next, statistical inference analysis was also conducted at the hypothesis testing stage through a one-way ANOVA test where the null hypothesis tested in the population (sample K) selected is the same. In other words, the sample $\mathrm{K}$ in each group is the same as the number of independent variable levels.

On the other hand, the alternative hypothesis refers to at least one or two groups that are significantly different from the other groups. Furthermore, this study also performed a Levene test for the homogeneity of each variance obtained from the analysis of variance to test and confirm the hypotheses. Subsequently, an ANOVA test was conducted to analyze the variance of the dependent variables. Regression analysis was also conducted to explain the strength of the relationship between variables. Hence, the ANOVA test determines the relationship between variables and the unstandardized beta coefficients to compare the strength of the effect of each independent variable on the dependent variable. Finally, linear regression analysis was performed to determine the unstandardized beta coefficients for the relationship between the independent and dependent variables. Overall, the data for this study were analyzed using the Statistical Package for the Social Sciences (SPSS) version 23 software. 


\section{Findings}

Table 1 Demographics of Respondents

Variable

\section{Frequency Percentage (\%)}

\section{Gender}

Male

77

37.6

Female

128

62.4

Total

Race

Malay

Chinese

29

14.1

Indian

20

9.8

Others

7

3.4

Total

205

100.0

Level of Education

Degree

Master's

PhD

Total

Year of Study

Year 1

Total

Field of Study

Social Sciences

Educational Sponsorship Resources

Scholarship

Education Loan

Self-Employed

Total

Family Income Category

Less than RM2,500

RM2,500 - RM4,849

RM4,850 - RM10,959 
Table 2 Reliability Test Analysis

\begin{tabular}{lcc}
\hline Item & Total Item & Cronbach Alpha Value \\
\hline Economic knowledge & 6 & 0.878 \\
The concept of needs and wants & 5 & 0.640 \\
Spending behavior & 5 & 0.626 \\
Understanding of saving & 5 & 0.862 \\
The effect of economic literacy on & 6 & 0.881 \\
students' financial behavior & &
\end{tabular}

Based on Table 1, the total 205 respondents involved $37.6 \%$ males and $62.4 \%$ females. Additionally, the respondents are mostly Malays with $72.7 \%$, followed by Chinese with $14.1 \%$, Indians with 9.8\%, while the remaining 3.4\% respondents are from other ethnics including Java, Bajau, Melanau, Brunei, and Murut. Next, in terms of the level of education, $74.6 \%$ of the respondents are Bachelor's degree students, while $19.5 \%$ of them are Master's students, and $\mathrm{PhD}$ students only constituted $5.9 \%$. In addition, $42.9 \%$ of the respondents, which is equivalent to 88 students, are 2 nd-year students, followed by those who are 3 rd-year students with $26.3 \%$ or equivalent to 54 .

As for the field of study, most of the respondents are social sciences students from the Faculty of Economics and Management, Faculty of Social Sciences, and so on with $62.9 \%$ or equivalent to 129 students, while students from the sciences fields include those from the Faculty of Science and Technology, Faculty of Engineering, and so on, which recorded a total of $37.1 \%$ or equivalent to 76. Moreover, a total of 112 respondents obtained financial resources through education loans such as PTPTN (54.6\%), followed by scholarships with $21 \%$ and equivalent to 43 students, and only $11.7 \%$ of the students use their own resources for daily expenses.

As for the family income category, a total of 108 respondents are from middle-income families from RM2,500 to RM4,849, followed by a total of 49 students and equivalent to $23.9 \%$ from families with an income below RM2,500. Next, Table 2 shows the reliability coefficient values for all items under economic literacy level. Overall, economic knowledge, understanding of saving, and the effect of economic literacy on students' financial behavior are at a high level. Meanwhile, the concept of needs and wants as well as spending behavior is at a moderate level. Thus, the results of this study are suitable to be discussed and further analyzed in detail. 
Table 3 Average Mean Value and Level for Each Item

\begin{tabular}{lcc}
\hline Item & Average Mean & Level \\
\hline Economic knowledge & 4.73 & High \\
The concept of needs and wants & 4.43 & High \\
Spending behavior & 3.82 & Medium \\
Understanding of saving & 4.49 & High \\
The effect of economic literacy on & 4.50 & High \\
students' financial behavior & &
\end{tabular}

Note: Financial literacy level scale: < 2.99 Low; 3.00-3.99 Medium; > 4 High (Rubayah et al., 2015)

Based on Table 3, economic literacy factors were measured in that the mean for each factor item was evaluated to identify the level of economic literacy of students. Accordingly, a mean value of 4.00 and above denotes a high mean value, while the mean value between 3.00 to 4.00 shows a moderate level of economic literacy and the mean value of 2.99 and below indicates that the students have a low level of economic literacy. On average, the findings of the study showed a high level of economic literacy, particularly on the item of economic knowledge with an average mean value of 4.73 .

Meanwhile, the item of the concept of needs and wants also showed a high level of economic literacy with a mean value of 4.43. This indicates that, holistically, the level of economic literacy with respect to economic knowledge and the concept of wants and needs among students is very good. This also proves that the students understand the aspects of basic needs such as food, shelter, and clothing. Subsequently, Table 3 shows the items for the financial behavior factors, namely spending behavior and understanding of saving.

On average, the mean value for the spending behavior item was at a moderate level with 3.82 , while the item of understanding of saving was at a high level with 4.49. Besides, Table 3 shows the measurement for the effect of economic literacy on student behavior. Overall, the average mean value for the effect of economic literacy on students' financial behavior was at a high level with 4.50. Thus, the result for the item of economic literacy impact showed that students are aware of the importance of economic literacy in ensuring that the problem of money scarcity does not occur in their daily expenses.

Table 4 Summary of Regression Analysis of the Relationship between Economic Literacy Level and Its Impact on Students' Financial Behavior

\begin{tabular}{lccccc}
\hline Variable & $R^{2}$ & $\operatorname{Beta}(\beta)$ & $t$ & $F$ & Sig. $(p)$ \\
\hline $\begin{array}{l}\text { Economic Literacy } \\
\text { Level }\end{array}$ & .410 & .640 & 11.867 & 140.816 & .000 \\
\hline
\end{tabular}

Linear regression analysis was conducted to examine the effect of economic literacy on students' financial behavior. Based on Table 4, there is a positive and significant effect of economic literacy on students' financial behavior with a value of $F=140.816, p<0.001$ and a value of $R^{2}=0.410$. This indicates that $41.0 \%$ of the variance was contributed by the economic literacy variable in predicting its impact on students' financial behavior and the regression pathway was significant at the $p<0.001$ level. Thus, the hypothesis that economic literacy has a significant effect on students' financial behavior is supported in this study. 
Overall, the regression analysis results for hypothesis testing supported a significant relationship. Hence, there is a significant relationship between the level of economic literacy and its impact on students' financial behavior.

Table 5 Respondents' Comments and Suggestions on How to Improve Economic Literacy Proficiency among Students

Respondent Feedback

3 Additional subjects related to financial management in schools and universities.

5

20

Emphasis on the subject of economic literacy since primary school.

Delivery of knowledge through courses or mass media.

$24 \quad$ Non-formal education at home should emphasize the aspects of financial management.

39 Spend prudently and do not waste.

$42 \quad$ Many seminars on economics to give more knowledge to students.

$46 \quad$ Plan and schedule daily expenses.

52 Students need to be aware of their own financial positions and learn how to manage their finances better.

65 Students themselves need to be aware and change their extravagant attitude in spending.

66 Make prudent decisions and be able to identify the needs or wants of a university student. Be frugal with one's existing finances.

68

Students themselves need to have the self-awareness to manage finances.

95

Economic and financial education should be applied as non-formal education at an early age by parents.

179

Economic literacy can be improved through parents at an early age.

Table 5 shows some feedback including comments and suggestions on how to improve the economic literacy of students given by some respondents. Most of the respondents opined that the level of economic literacy among students is at a relatively low and weak level for several reasons. For instance, the 66th and 68th respondents gave opined that the low level of economic literacy among students is because the students cannot distinguish between the 
importance of the concept of needs and the concept of wants and they also do not have the self-awareness to manage their finances well.

In addition, students are more likely to be influenced by their peers in overspending; hence, the 65th respondent opined that the extravagant attitude of students is one of the reasons why they are unable to control their daily expenses and, in turn, causing the students to fail in financial management. However, a few respondents stated that the level of economic literacy among students is at a moderate level, which is considered a relatively satisfactory situation. This can be shown through the opinion of the 46th respondent who stated that, by looking at the way students use financial resources, one can describe the method of financial management of those students.

However, in this study, most of the suggestions given by the respondents are more focused on components such as the addition of learning subjects or programs in schools or universities. Other than that, some respondents also gave suggestions such as providing or exposing education through social media or mass media including making short videos containing information about the economy in relation to financial management to be uploaded to social sites such as Facebook, YouTube, and so on. The next proposal includes adding compulsory economics subjects related to financial management where the emphasis should be given since primary school.

This allows children to be exposed to the importance of economic literacy consistently until they become adults and are able to control their spending and practice proper financial management in their daily life. Furthermore, the 42nd respondents suggested holding seminars or campaigns on economics and financial management to all students with the aim of providing knowledge on the strategies related to good financial management. Overall, these suggestions can indirectly help society become wiser in making decisions related to finances without making any mistakes in financial management decisions. Holistically, the level of economic literacy among students is at a high level and the same goes for the impact of economic literacy on students' financial behavior. Hence, the study found that the items of economic knowledge, the concepts of needs and wants, as well as the understanding of saving are significant in influencing the impact of economic literacy on students' financial behavior.

\section{Discussion and Recommendations}

First of all, Aisyah and Wajeeha (2016) stated that a high level of literacy, regardless of undergraduate or postgraduate students, will affect the way students manage their finances. While Salbiah et al. (2018) stated that a high level of economic knowledge can influence students' financial behavior, the way of financial management is, however, not influenced by the spending behavior of students. This is because most of the students do not plan or manage their expenses well. Students also perceive that money sources are easily obtained from education loans, scholarships, and also parental funding (Yasmin \& Anuar, 2017).

Based on the results on educational resources, we can see that as many as 181 students of equivalent to $88.3 \%$ of them are funded by their parents, scholarships, and even educational loans on a monthly basis. Therefore, this may cause the students to be less sensitive and concerned about the amount of their expenses, making them more likely to adopt extravagant behavior in their daily life. Hence, without a high economic literacy level among 
students, they will face various life problems in the future. According to Sinar (2020), Bank Negara Malaysia (BNM) reported that $75 \%$ of Malaysians do not have savings or savings of less than one thousand Malaysian ringgit.

Furthermore, individuals tend to borrow money from any agent including those without a license due to the scarcity of money to cover their living costs (Selvanathan et al., 2016). Therefore, this study provides several suggestions, for instance, implementing and increasing awareness of the importance of economic literacy among university students. Rubayah et al. (2015) stated that students' knowledge needs to be enhanced and early exposure needs to be applied in order to adapt to the materialistic lifestyle conditions of society in the present time (Sabri \& Alavi, 2019).

Moreover, the suggestion to increase the level of economic literacy among students is also aimed at making the national education system a platform to form educational networks starting from primary school until higher levels of education such as polytechnics, universities, and so on. In addition, consumer associations and clubs at the school level need to be fully utilized so that the economic literacy element does not only involve curricular aspects but also co-curricular aspects. Therefore, students are able to understand the relationship between theoretical economic literacy and the relevant practical elements. As such, economic literacy becomes lifelong knowledge that needs to be improved at all life stages.

The next suggestion is to hold programs or campaigns related to the community, especially students to improve their literacy on economics related to financial management. According to Sabri and Alavi (2019), the existence of programs related to economics and finance will make it easier for the community to receive counseling and advice in managing their finances. Furthermore, as stated by Sabri and Alavi (2019), a person's financial behavior is also influenced by the role of socialization agents, namely teachers and parents.

This situation is consistent with the current study whereby the behavior and interaction that occurs between individuals and socializing agents on a regular basis is positively related to the level of literacy of an individual. This suggestion was also given by the respondents who emphasized that family agencies should play a role as informal educational agents in providing exposure to their children about the economy as well as the proper way of financial management. This is because, the community members will be able to manage their finances better if they are given basic knowledge of financial management from the beginning. Hence, this implies the need to educate children when they are young; striking while the iron is hot.

\section{Conclusion}

There are some limitations to this study. For instance, this study is only limited to students who pursue their studies at a public university. Besides, the study is also limited to incomprehensive time and information because it was difficult to obtain information due to the current COVID-19 pandemic. Since the findings have shown that the level of economic literacy among students is at a high level and that the financial behavior of students in terms of spending is at a moderate level, economic literacy indeed has a significant influence on students' financial behavior. Besides, the respondents are also aware of the real fact that, if they have a high level of economic literacy, then they will no longer experience money scarcity. 
This is because the high level of economic knowledge in relation to finances can lead to a wise society that reduces the burden of a country and increase the economic growth of the country. Evidently, most developing countries still have high poverty rates (Zakaria et al., 2021), which causes various social problems to occur and one of the factors influencing the occurrence of poverty is the issue of debts incurred by individuals. Thus, individuals who can manage finances will indirectly improve their standards of living. In this regard, a society that utilizes knowledge and skills in finance can ensure a better life in the future (Sabri \& Alavi, 2019).

In accordance for that reason, higher educational institutions should play an important role in improving economic literacy among students. Exposure to that information should not be concentrated only through the specific subject lectures. This knowledge needs to be conveyed from various angles, such as programs, campaign, and competition. Technological revolutions need to be utilized optimally. New social media applications such as instagram or tik tok should be used to convey information to students informally. Socioeconomic conditions in the future will be more challenging, hence, economic literacy is a requirement for students to manage available resources for a better life. To ensure the well-being of the future, the country needs people who are informed, wise in managing resources and capable in defending their rights and responsibilities as consumers for future life.

\section{Acknowledgements}

This research was funded by Universiti Kebangsaan Malaysia under grant code: GG-2020007.

\section{References}

Aisyah, A. R., \& Wajeeha, Z. (2016). Faktor Penentu Pengurusan Kewangan: Kes Mahasiswa Universiti Kebangsaan Malaysia. Jurnal Personalia Pelajar, 19(2), 85-94.

Bhushan, P., \& Medury, Y. (2014). An Empirical Analysis Of Inter Linkages between Financial Attitudes, Financial Behaviour and Financial Knowledge of Salaried Individuals. Indian Journal of Commerce and Management Studies, 5(3), 58.

Hasan, N. A. A., Ahmad, N., \& Razak, N. A. A. (2017). Factors that significantly affect college students' CGPA. International Academic Research Journal of Social Science, 3(1), 7781.

Huriyatul, A., \& Yogi, E. S. (2016). Analisis Tingkat Literasi Kewangan. Jurnal Ekonomi Dan Bisnis Islam, 1(2), 235-244.

Husniyah, A. R., \& Mohd, F. S. (2014). Malaysian Public Sector Employees' Financial Preparedness and Personal Financial Plan Implementation. Journal of Wealth Management \& Financial Planning 1, 33-43.

Hussin, N. L., \& Rosli, L. S. (2019). Literasi kewangan dalam kalangan pelajar di Kuim. Journal of Business Innovation, 4(1), 102-110.

Khoong, T. W. (2017). Perancangan Kewangan Dan Aplikasi Teori Tingkah Laku Kewangan Dan Teori Keperluan Maslow: Kajian Kes KWSP Di Malaysia. Geografia-Malaysian Journal of Society and Space, 12(8).

Khoong, T. W. (2015). Evidence of Behavioral Finance Theory in Financial Planning: An Empirical Study of the Employees Provident Fund (Epf) Retirement Scheme in Malaysia. Journal of Wealth Management \& Financial Planning 2, 3-16. 
Mitchell, O. S., Lusardi, A., \& Curto, V. (2009). Financial Literacy among the Young: Evidence and Implications for Consumer Policy. Pension Research Council WP, 9.

Rubayah, Y., Hawati, J., \& Nur Ain, K. (2015). Tahap Literasi Kewangan Dalam Kalangan Pelajar Universiti Awam: Kajian di Universiti Kebangsaan Malaysia. Jurnal Personalia Pelajar, 18(1), 75 - 88.

Sabri, N. I. H., \& Alavi, K. (2019). Meneroka Literasi Perancangan Kewangan Belia B40 Berpandukan Pendidikan Psiko-sosial. Jurnal Wacana Sarjana, 3(1), 1-8.

Salbiah, N. S. A., Suzana, A. R., Suhailah, I., Nurulhayah, M., \& Maryam, M. E. (2018). Amalan Pengurusan Kewangan Mahasiswa. Journal of Business Innovation, 3(2), 9-23.

Selvanathan, M., Krisnan, U. D., \& Wen, W. C. (2016). Factors effecting towards personal bankruptcy among residents: case study in Klang valley, Malaysia. International Journal of Human Resource Studies, 6(3), 98-109.

Sinar, H. (2020). Ramai Tiada Wang Simpanan Kecemasan. Retrieved June 22, 2021 from https://www.sinarharian.com.my/article/67672/Analisis-Sinar/Ramai-tiada-wangsimpanan-kecemasan

Talib, N. A., Yahaya, R., \& Jusoh, M. A. (2017). Financial Education Resource, Level of Financial Literacy and Its Relationship with Financial Behaviour among Entrepreneurs at North Zone Mini RTC. International Journal of Accounting, Finance and Business, 2 (5), 123 135.

Wahid, H., \& Zahari, S. A. (2020). Literasi Kewangan Dan Kesannya Terhadap Gelagat Perbelanjaan Mahasiswa Di Universiti Kebangsan Malaysia. Jurnal Personalia Pelajar 23(1), 27-43.

Yasmin, H. A., \& Anuar, A. (2017). Tahap Literasi Kewangan Di Kalangan Mahasiswa. Persidangan Antarabangsa Mengenai Pendidikan Global 5, 2373-2387. Anjuran Universiti Ekasakti Padang.

Zakaria, M. S., Sahid, S., \& Othman, N. (2021). Tahap Budaya Keusahawanan dan Kepimpinan Keusahawanan serta Hubungannya dengan Minda Keusahawanan Anak-Anak Golongan Asnaf. Malaysian Journal of Social Sciences and Humanities (MJSSH), 6(3), 104-119. 